\title{
Magdalena Kocoł
}

\author{
Uniwersytet Jagielloński
}

\section{WYCHOWUJACC DZIECKO W... NORWEGII}

\section{Abstract \\ Raising a child in... Norway}

The aim of the essay is to present the differences in the approach to raising children that exist in Poland and Norway, and to present the specificity of the activities undertaken by the controversial Barnevernet institution. It is also an objective discussion of differences in relations between parents and offspring, understanding and development of the idea of children's empowerment and forms of discrimination both in the family and from the so-called welfare state.

Key words: upbringing, childhood, Barnevernet, welfare state

\section{Wprowadzenie}

W Europie XXI wieku ukształtowało się kilka postaw państwa wobec rodziców i ich metod wychowywania potomstwa. Ciekawe informacje o olbrzymich rozbieżnościach między sposobami, w jakie instytucje państwowe w Polsce i Norwegii ingerują i pilnują bądź też wspierają i pomagają rodzinom w tej kwestii przedstawia reportaż Macieja Czarneckiego Dzieci Norwegii. O państwie (nad)opiekuńczym. Autor jest dziennikarzem działu zagranicznego „Gazety Wyborczej”. Publikuje także w „Dużym Formacie”, „Wysokich Obcasach” i „Magazynie Świątecznym”. Jest absolwentem prawa i antropologii kulturowej. Zajmuje się głównie niszowymi kwestiami społecznymi - takimi problemami, o których istnieniu społeczeństwo danego państwa często nawet nie zdaje sobie sprawy (Maciej Czarnecki). Nie posiada on wykształcenia pedagogicznego, ale bardzo obiektywnie i na chłodno przeanalizował sytuację odbierania dzieci polskim rodzinom przez Barnevernet (tamtejszy urząd ochrony dzieci) w Norwegii. W swojej książce opisuje polski oraz norweski sposób wychowywania potomstwa. W żaden sposób nie staje po żadnej ze stron - bardziej stara się każdą z nich zrozumieć niż osądzać. Dokładnie opisuje uczucia i historie swoich bohaterów, a także sam sprawdza stereotypy krążące zarówno w społeczeństwie polskim, jak i w norweskim. Zdecydowałam się omówić temat

* Studentka studiów II stopnia na kierunku praca socjalna, Instytut Socjologii UJ. 
dzieciństwa w kalejdoskopie właśnie na przykładzie tej książki, ponieważ porównuje ona dwa typy wychowania oraz zaangażowanie instytucji państwowych, w tym pracowników socjalnych, w ten proces. Ogromnie ujęło mnie w tym reportażu przedstawienie dzieciństwa, relacji, empatii, podmiotowości w dwóch tak różnych od siebie społeczeństwach. Myślę, że oba kraje mogłyby się wiele od siebie nauczyć.

\section{Dziecko polskie, dziecko norweskie a Barnevernet}

Kluczowym założeniem autora w kwestii wychowania dzieci jest podejście do niej norweskiego Barnevernetu, w szczególności w stosunku do Polaków. Instytucja ta postrzegana jest w większości przypadków negatywnie - jako zabierająca rodzicom dzieci, rozdzielająca rodziny. Podstawa to zauważenie różnic kulturowych między Norwegią a Polską, które odnoszą się również do opiekowania się dziećmi.

Czarnecki w reportażu nie ujawnia swojego podejścia do sposobu wychowywania potomstwa, jednakże przytacza kluczowe rozbieżności w tej kwestii, jakie występują między tymi dwoma krajami. Norweskie dziecko według jego rodziców jest silne i niezależne. Często bawi się na świeżym powietrzu, rodzice spędzają z nim dużo czasu, szczególnie aktywnie, sportowo. Stawiają na wielotorowy rozwój potomka. Dziecku nie wolno dawać klapsów, ciągnąć za ucho. Norweskie rodziny wydają się bardziej przyjazne i partnerskie dla dziecka niż te polskie, konflikty rozwiązują przez rozmowę. My, Polacy, zagonieni, często nie mamy czasu dla dzieci, nie jesteśmy dla nich dobrym przykładem tego, jak można spędzać wolny czas, ponieważ po prostu go nie mamy. Jesteśmy w większym stopniu ekspresywni, często krzyczymy, twardo wyznaczany dzieciom granice i dokładnie to egzekwujemy. Gdy je przekroczą, zostają im wymierzone kary (na przykład w postaci klapsów czy głośnej awantury). W Norwegii natomiast mówi się o konsekwencjach. Jeśli przedszkolak nie chce ubrać kurtki, a na zewnątrz panuje mróz, Polka da mu klapsa i ubierze na siłę. Norweżka pozwoli mu wyjść na zewnątrz, aby na własnej skórze przekonał się, jak jest zimno, i sam poprosił o kurtkę. Polacy są romantyczni, emocjonalni, a Norwegowie pozytywistyczni i racjonalni. Nasze tradycje stoją w sprzeczności, nie współgrają ze sobą.

Polskie dzieci bądź dzieci Polaków, które urodziły się już w Norwegii, wielokrotnie są dyskryminowane w procesie wychowawczym. Dorośli Polacy będący rodzicami w Norwegii uważają, że wiedzą, co jest najlepsze dla ich dzieci oraz że polski model wychowania zasługuje na największe uznanie. Tymczasem niepełnoletni Polacy oraz ich zdanie są szczególnie dyskryminowani w przypadku pojawienia się problemów w rodzinie, a co za tym idzie - wszczęcia postępowania przez instytucję Barnevernet. Często lekceważy się stanowisko dziecka, przywiązuje wagę do jednej wypowiedzi, zabiera z domu bez informowania rodziców, manipuluje bądź nie szanuje prawa do polskiej tożsamości, zakazując mówienia w języku ojczystym. W Polsce, mimo iż rodzina nie radzi sobie z opieką, dziecka zazwyczaj się nie słucha, zostaje w domowym piekle wraz z lękiem i nadzieją, że rodzice się opamiętają. Odebrane z rodzin biologicznych dzieci nie mają wpływu na częstotliwość spotkań z ojcem i matką - niektóre kłamstwa wypowiedziane, 
by wymusić coś na rodzicach, zostają uznane za prawdę; tego nie da się cofnąć. Mimo iż dzieci żałują tego, co zrobiły, przyznają się do tego rodzicom, to Barnevernet nie chce uznać zmiany ich stanowisk. Ich głos w przypadku spraw instytucjonalnych, już po wszczęciu procedury, praktycznie się nie liczy.

\section{Relacja partnerska czy hierarchiczna?}

Dla Norwegów pozycja dziecka w społeczeństwie w relacji do pozycji dorosłych jest bardzo partnerska - szanują oni autonomię dziecka. Już siedmiolatek może wypowiadać się w kwestiach, które bezpośrednio go dotyczą, a sądy powinny brać pod uwagę jego zdanie na przykład w sprawach o prawo do opieki (nawet młodsze dzieci mogą zostać przesłuchane bez obecności rodzica). W wieku piętnastu lat dziecko posiada już pełne prawo do decydowania o wyborze szkoły i kwestiach poglądów, religii. W tej kulturze należy pytać dziecko, jak się czuje, co myśli na dany temat; niekoniecznie podporządkowywać się jego zdaniu, lecz zapewniać, że jego uczucia są brane pod uwagę przy podejmowaniu decyzji. Ze względu na wyższy status materialny Norwegów i dużą swobodę w wychowaniu polskie dzieci patrzące na ich rówieśników w tym kraju często szantażują rodziców, by na przykład dostać nowego iPhone’a (Czarnecki 2016: 138). W Polsce, szczególnie w wielodzietnych rodzinach, nadal panuje jeszcze przekonanie, że rodzina to rzecz święta, a zdanie ojca jest najważniejsze („dzieci i ryby głosu nie mają”). Występuje hierarchia i dzieci muszą się podporządkować zdaniu rodziców. Nie jest to złe, ponieważ rodzic nie daje „wejść sobie na głowę”, a dziecko zna zasady i szanuje zdanie innych. W naszym państwie jednak wiele się zmienia w tej kwestii. Coraz bardziej popularne stają się tak zwane bezstresowe wychowanie (w którym dominującą rolę pełni dziecko) oraz zarządzanie dzieciństwem (w którym to dorosły decyduje o kierunku rozwoju dziecka „wysokiej jakości”).

\section{Rola dorosłego w umacnianiu dziecka}

Autor książki kilkukrotnie podkreśla przejawy „umacniania” dziecka w systemie wychowania w Norwegii i możliwości podejmowania przez niego decyzji. Odnosi się to w pierwszej kolejności do kwestii rozwoju, w szczególności w kraju, który stwarza ku temu fantastyczne możliwości. Zarówno rodzice, jak i szkoła szukają w dzieciach najmocniejszych stron, tego, co je wyróżnia. Podchodzą do nich indywidualnie i rozwijają ich talenty. Zwracają większą uwagę na zalety i zdolności niż wady i „bycie gorszym w porównaniu z innymi” w niektórych zadaniach czy przedmiotach. Norwegia wypracowała taki system, w którym czuwa się nad rozwojem dziecka, dostrzega problemy i zaradza im już w zarodku, działa ochronnie, profilaktycznie, a nie „po fakcie”, między innymi w kwestii przemocy czy molestowania seksualnego. Kontrowersyjne jest natomiast to, że trudno nam, Polakom, zaakceptować stwierdzenie, że „w najlepszym interesie dziecka jest żyć w warunkach sprzyjających jego rozwojowi, niekoniecznie 
z rodzicami biologicznymi" (Czarnecki 2016: 20). Odebrane z trudnych rodzin dzieci trafiają zazwyczaj do profesjonalnych rodzin zastępczych (a nie krewnych) i zwraca się je rodzicom po długim czasie (o ile w ogóle do tego dochodzi). Państwo prawie nigdy nie przyznaje opieki nad nim wujkom czy babciom, gdyż są oni za blisko związani z rodzicami dziecka i mogliby nieformalnie przekazać je z powrotem do złych warunków rodzinnych. Dodatkowo jeśli Barnevernet stwierdzi, że dziecko przywiązało się zbytnio do nowych opiekunów i zabranie go z rodziny zastępczej może wywołać „poważne problemy”, to nie zwraca się go rodzinie biologicznej. Bierze się pod uwagę rozwój dziecka, ale nie jego uczucia w stosunku do rodzica oraz emocje rodzica w trudnej dla niego sytuacji izolacji od tego, co dla niego najcenniejsze, czyli potomstwa. W Norwegii panuje przekonanie, że nikt nie zadba lepiej o dobro nieletniego niż państwo, a rodzina nie zawsze jest najważniejsza. Kluczowy jest właściwy rozwój.

Rola dorosłego, rodzica, wychowawcy, urzędników społecznych, lekarzy itp. w wychowaniu dziecka jest bardzo duża. Służby ochrony dzieci w Norwegii są dużo bardziej rozbudowane niż w Polsce oraz działają szybciej i częściej. Nauczyciele, przedszkolanki, pielęgniarki itd. mają obowiązek zgłaszania podejrzeń stosowania przemocy. Tak też jest w praktyce, ponieważ większość alarmowych informacji do Barnevernet dociera właśnie od nich. Urzędnicy tej instytucji często odwiedzają domy, w których podejrzewa się, że stosowana jest przemoc, rozmawiają z dziećmi sam na sam. Bardzo szybko rozpoczynają postępowanie, dlatego często dochodzi do nadużyć. Barnevernet ma również obowiązek zaproponować pomoc, na przykład zapewnić darmową opiekę, pomoc w nauce, zasiłki. Rodzice jednak często boją się z niej korzystać, co tylko utrudnia współpracę. W 2010 roku polskim pracownikom socjalnym przyznano zbliżone do norweskich uprawnienia do odebrania dziecka bez wyroku sądu w sytuacji zagrożenia jego zdrowia lub życia. W 2014 roku w Polsce odebrano tym sposobem porównywalną liczbę dzieci, co w Norwegii, jednak w naszym kraju mieszka o sześć milionów dzieci więcej.

Norwegia jest idealnym przykładem państwa opiekuńczego. Oferuje rodzinom szeroką pomoc, jak na przykład długie urlopy wychowawcze, doradztwo, ale też bardzo szybko wkracza, gdy tylko pojawią się sygnały, że coś dzieje się źle, a także gdy dzieci mają trudność w adaptacji w nowym środowisku, problemy w nauce itp. Polska zaś zarówno daje mniej, jak i wymaga mniej od wychowawców, pracowników socjalnych czy rodziców. W Norwegii przedszkolanki pozwalają dzieciom taplać się w błocie, wychodzić na deszcz i mróz, lekarze wolą, by naturalnie pokonywały choroby - rzadziej przepisują antybiotyki. U nas na dziecko „chucha się i dmucha”, bacznie obserwuje, żeby nie zrobiło sobie krzywdy, a rodzice wręcz zmuszają lekarzy do przepisywania antybiotyków. Norweski system nauczania i sposób kontaktowania się wychowawców z rodzicami jest zupełnie odmienny od polskiego. Nie ma klasowych wywiadówek, a z rodzicem spotyka się indywidualnie. Jest to forma rozmowy (a nie wypominanie czy suche przekazywanie informacji), dzielenie się doświadczeniami i szukanie płaszczyzny porozumienia co do przyszłego rozwoju dziecka. Podstawą jest indywidualizm, a nie porównywanie z innymi. 


\section{Podsumowanie}

W trakcie czytania reportażu pojawiało mi się wiele refleksji (które w większości zawarłam w eseju) i uważam, że dzięki niemu wiele się nauczyłam. Przede wszystkim uwrażliwiłam się na różnice kulturowe, które odnoszą się nie tylko do kwestii tradycji, religii, posiłków, ale i wychowywania potomstwa czy działania państwa w stosunku do najmniejszej komórki społecznej, jaką jest rodzina. Każdy naród uważa swój sposób opieki nad dzieckiem za najlepszy, jednak emigrując, zapominamy o szacunku i zrozumieniu odmiennych stanowisk i zachowań. W każdym ze sposobów można odnaleźć plusy i minusy. Sądzę jednak, że mi samej byłoby trudno dopasować się do systemu wychowawczego Norwegii, ponieważ jestem osobą temperamentną i wybuchową. Z drugiej strony bardzo pochwalam podejście przedszkolanek i nauczycieli, które dbają o rozwój dziecka, a nie o oceny i zdawanie egzaminów. Także dbanie o kontakt dziecka z naturą, aktywny wypoczynek, naturalne metody leczenia to styl, w jakim chciałabym wychowywać swoje przyszłe dzieci. Sądzę, że ten typ zaangażowania rodzicielskiego jest najbliższy modelowi „generatywnej troski” Anny Kwak (2012). Wymaga od dorosłego plastyczności, dialogu, relacji i rozmowy, a przede wszystkim przestrzeni dla dziecka jako partnera. Uważam, że tę książkę powinni przeczytać wszyscy Polacy, którzy wybierają się do Norwegii wraz z dziećmi. Nie ku przestrodze przed „strasznym” systemem, ale po to, by uwrażliwić się na różnice kulturowe i zrozumieć, że nie ma idealnego sposobu wychowania. Liczy się po prostu miłość i dobro dziecka.

\section{Bibliografia}

Czarnecki M. (2016). Dzieci Norwegii. O państwie (nad)opiekuńczym. Wydawnictwo Czarne, Wołowiec.

Kwak A. (2012). Rodzicielstwo - inwestycja w przyszłość. Czy zawsze udana?, w: J. Brągiel, B. Górnicka (red.), Rodzicielstwo w kontekście współczesnych przemian społecznych. Wydawnictwo Uniwersytetu Opolskiego, Opole.

Maciej Czarnecki (b.d.w.); https://czarne.com.pl/katalog/autorzy/maciej-czarnecki (dostęp: 7.01.2020). 